\title{
Norwegian and Croatian Students of Undergraduate Kindergarten Teacher Education Programs on Their Professional Development and Conditions for It
}

\author{
Alicja R. Sadownik ${ }^{1, *}$, Wenche Aasen ${ }^{2}$, Adrijana Visnjic Jevtic ${ }^{3}$ \\ ${ }^{1}$ Kindergarten Knowledge Centre for Systemic Research on Diversity and Sustainable Futures, \\ Western Norway University of Applied Sciences, Bergen, Norway \\ ${ }^{2}$ Western Norway University of Applied Sciences, Bergen, Norway \\ ${ }^{3}$ University of Zagreb, Faculty of Teacher Education, Croatia
}

Copyright $\bigcirc 2019$ by authors, all rights reserved. Authors agree that this article remains permanently open access under the terms of the Creative Commons Attribution License 4.0 International License

\begin{abstract}
This article presents Norwegian and Croatian students' perspectives on conditions for their professional growth during undergraduate kindergarten teacher education. The data gathered through focus group interviews are theorized using the cultural-historical wholeness approach that identifies institutional conditions for the development of certain motivations and acts. Since the students from the two countries generally perceive the institutional conditions for their learning as insufficient, the conclusions refer to certain institutional practices that could strengthen the development of competences that students recognize as the most relevant. These competences to act grow at the intersection of theory and practice.
\end{abstract}

Keywords Kindergarten Teacher Education, Student Perspective, Joining Theory and Practice, Competences to Act, Professional Growth, Conditions

\section{Introduction}

This paper uses the cultural-historical wholeness approach [1,2] to analyze students' own perceptions of conditions for their professional development provided by higher education institutions. The students analyzed in this paper attend two higher education institutions providing kindergarten teacher education programs in two different countries-Norway and Croatia.

Since, kindergarten teacher education is strongly related to the cultural and social values connected to a good childhood and good (child)care, the models of kindergarten teacher education programs are first presented in their socio-cultural contexts in which the legislative apparatuses forming the national guidelines for teacher education and cultural values are presented.

After this, the institutional level is described since two different societies implement various sets of activity settings that are important and relevant for the formation of students. However, it is not always only culture and values that determine institutional practice, economic and intellectual resources are also significant elements that compromise visions and cultural ideals; in this case of kindergarten teacher education.

In the empirical part of this paper the personal level of student experiences of various institutional practices as conditions for their professional development is presented and discussed. The conclusions refer to needs for certain practices that are important both internationally and locally to support the professional, theoretical, and practical formation of kindergarten teachers.

\section{The Cultural-historical Wholeness Approach}

Marianne Hedegaard [1,3,4] analyzes individual's motives for actions and actions in relation to the conditions created at the levels of institutions in which individuals participate and at cultural and societal levels at which the institutions are established. She developed a model of societal conditions for cultural practice that includes the perspectives of the state, the institution, and the individual, which is applied in this paper to examine students' perceptions of institutional conditions supporting their professional development. Although Hedegaard's model is based on research with children, we apply it to research on adult students. This "transplantation" of the model is based on our interpretation of Hedegaard's theory that we understand as primarily focused on the societal and institutional conditioning of individuals' motives and 
actions and less focused on the age and developmental stage of the individuals (children or adults). In certain institutional contexts, for example, family, kindergarten, school, or work, there are different expectations and demands imposed on individuals. They respond to them in various ways by developing diverse arrays of motivations (which are not always in line with expectations) and activities.

Figure 1 below presents the various levels of conditions and individual activity. "The state perspective," which is also known as the "society perspective"[5], contains a historically developed context for society, where the state apparatus, in the form of laws, statutory instruments, and the institutionalization of practices, provides frameworks for child and youth participation in activities.

"The institutional perspective's concern is about everyday practice in institutions. This everyday practice has to be seen as knotting together traditions and values with personal motives and competences" [4:73]. Just as the previous one, this dimension is rooted in the dominant culture, but also in available resources. As mentioned above, culture cannot be used as an explanation for all institutional solutions; access to different kinds of goods and resources is equally important [6]. The Norwegian and Croatian higher education institutions for kindergarten teacher education have access to uncomparable economic resources that influence the ways kindergarten teacher education is organized in these countries, and, thereby, the various activity settings provided to the student groups (of different sizes).

The individual level in this paper is based on empirical study with the participation of Norwegian and Croatian kindergarten teacher education students. The study tries to reconstruct their perceptions of the institutional conditions and practices that support their professional growth.

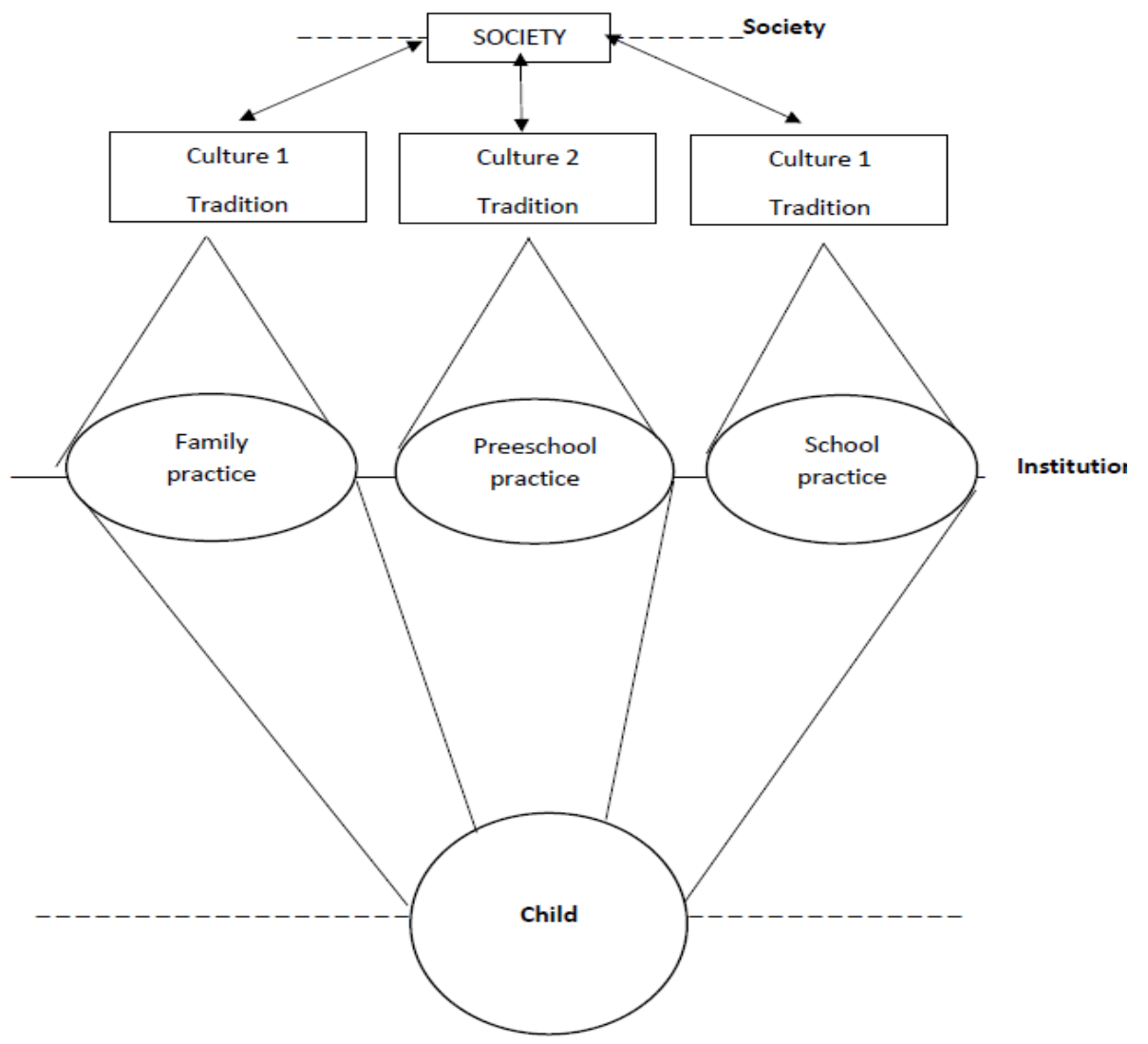

Figure 1. A model of children's learning and development through participation in institutional practice. Source: [4: 73]. 


\section{Norwegian Kindergarten Teacher Education - State Level}

Within the Norwegian context, the kindergarten teacher is a profession, which means that it builds on a societal need for a certain job that requires special knowledge and an ethical approach. In Norway, kindergarten teachers must graduate from a three-year bachelor's degree program in kindergarten teacher education. Upon graduation, they are educated professionals who are ready to work in kindergartens as teachers or educational leaders. ${ }^{1}$ Since kindergartens are important in realizing the ideals of gender equality, providing all children with equal opportunities regardless of socio-economic background, and also realizing the Nordic ideal of a good childhood [7], kindergarten teacher education is a necessary tool that forms teachers who, again, safeguard the high quality realization of societal needs.

Since the profession of kindergarten teacher is rooted in the needs of the whole society, it is at the state level where guidelines and regulations for it are established. The last reform of the kindergarten teacher education was conducted in 2012 with the aims of making it more relevant to the needs of the field and continually changing society. It is based on the evaluation of the older kindergarten teacher education model that was lacking in research-based knowledge and was insufficiently professionally oriented [8]. This is why the reformed model replaced scientific disciplines with interdisciplinary areas of knowledge, which are meant to respond more relevantly to the complex, interdisciplinary character of daily functioning of kindergartens and also to introduce the students to interdisciplinary research. The interdisciplinary areas of knowledge in the current kindergarten teacher education program are as follows:

- child development, play, and learning;

- $\quad$ art, culture, and creativity;

- $\quad$ social sciences, religion, and ethics;

- $\quad$ language, text, and mathematics;

- $\quad$ nature, health, and motion;

- leadership, cooperation, and developmental work.

Additionally during the third year of studies, the students can choose a specialization (20 ECTS credits) and work on their research-based bachelor's theses. Regardless of the general interdisciplinary character of the course of study, the subject of pedagogy plays a special role. It is supposed to delve into "all areas of knowledge and is responsible for the general coherence among them and for students'

1 Teacher or educational leader-Norwegian kindergartens are organized in units lead by educational leaders. Staff norms require one kindergarten teacher per kindergarten unit (18 children aged 3-6, or 10 children aged $0-3$ ) and one or two assistants who do not have to have any qualifications. This is a new rule that has not yet been implemented. The former staff norms required only one educational leader per kindergarten unit (10 small or 18 older children). professional and personal growth. The responsibility of pedagogy in the profession-oriented dimension of the educational program is of equal importance" [7, see also 9].

To a certain degree, all the areas of knowledge must be run in a research-oriented and practice-related way. When it comes to the practice-related dimension, the National Guidelines for Kindergarten Teacher Education impose on each student 100 days of obligatory practical training under the supervision of in-service teachers working in kindergartens. In order to safeguard the quality of in-service mentoring, in-service teachers must complete a mentoring course of 18 ECTS credits. Moreover, in-service teachers must be cognizant of the newest literature and research reports used in the kindergarten teacher education program to allow them to facilitate student competences that intersect theory and practice. However, this is not always realized in the field, because kindergarten teachers focus more directly on their work in kindergartens, and their office time is used to document their own practice.

\section{Croatian Kindergarten Teacher Education - State Level}

Kindergarten teacher education in the Republic of Croatia started in 1880 with a one-year course for future teachers in play schools. These teachers, who were pioneers in kindergarten education, were supposed to master the subjects of religion, teaching and play theory, practical exercises in play schools, language, art, singing, and exercising [10]. Since then, numerous reforms in teacher education have been implemented that have been based primarily on contemporary research into child development and learning theories that are in line with the cultural ideal of childhood as a time for all-round development. The UN Convention on the Rights of the Child [11] played a significant role in creating the cultural ideal of a good childhood. Since the ratification of the convention, children has been seen as rights holders and active, competent actors in their lives, and explorers of their environments who must be supported in developmental processes [12]. The recognition of children as actors together with respect for children's perspectives has prompted various discussions on children's positions in society, early education and care offers, and, thus, kindergarten teachers $[12,13,14,15]$.

Today's teachers are expected to be experts in the area of pedagogy and have knowledge of all areas that may be of interest to early and pre-school children (arts, natural sciences, social sciences), and expectations are that these teachers are multidisciplinary experts [16]. This imposes pressure on universities that have to follow ministerial demands of the profession when developing kindergarten teacher education programs, while remaining in compliance with the Bologna Declaration that, in 2013, transformed kindergarten teacher education into three-year 
undergraduate university course of study. As long as they remain in line with national and international policy documents, universities have autonomy in developing their study programs for kindergarten teachers. This renders comparing kindergarten teacher education programs among universities very difficult.

With regard to policy documents that describe the curricula of courses of study, it is important to mention that the State Pedagogical Standard of the Republic of Croatia [17] defines kindergarten teachers as professionals who perform educational work with children; are able to plan and evaluate their educational work; collect, develop and maintain resources for working with children; are able to engage with children at all developmental levels and meet their needs; encourage the development of every child according to his/her abilities; have competences and are able to collaborate with parents, other professionals, and expert teams in kindergartens and with other actors in children's lives. In the langue of various scientific disciplines, teachers should have knowledge and skills in pedagogy, psychology, language (mother tongue and foreign languages), literacy, art, music, kinesiology, statistics, STEM subjects, and didactic practices in various subjects. While subjects may vary among universities, the outcomes of the courses of study are similar to those described in the Pedagogical Standard [17]. In addition to a degree qualification, teachers must complete one-year internships and pass a state exam before entering the profession.

\section{The Institutionalization of Kindergarten Teacher Education - a University College from Norway}

In the researched institution driving kindergarten teacher education in Norway, the various areas of knowledge were organized to provide students with the additional possibility to choose one of four profiles that, in practice, were specializations in four of the existing areas of knowledge: a) child development, play, and learning; b) art, culture, and creativity; c) nature, health, and motion, or d) language, text, and mathematics. Regardless of the choice of profile, students graduate as fully qualified kindergarten teachers with 40 ECTS credits in the area of knowledge that constitutes the profiles (and with 20 ECTS credits in each of all the other areas of knowledge). The specialization course is completed in the third year of study together with the bachelor's thesis and the area of knowledge of leadership, cooperation, and developmental work.

The other areas of knowledge are distributed as follows throughout the course of study.

Regarding the role of pedagogy that contributes all the areas of knowledge with the aim of creating coherence, it focused on various issues, which are presented in the table
2 below, during the various years of the course of study.

Table 1. Overview of areas of knowledge during the three years of the undergraduate kindergarten teacher education course of study of in Norway

\begin{tabular}{|c|c|}
\hline Course year & Areas of knowledge \\
\hline $1^{\text {st }}$ & $\begin{array}{l}\text { child development, play, and learning } \\
\text { art, culture, and creativity }\end{array}$ \\
\hline $2^{\text {nd }}$ & $\begin{array}{l}\text { nature, health, and motion } \\
\text { language, text, and mathematics } \\
\text { social sciences, religion, and ethics }\end{array}$ \\
\hline $3^{\text {rd }}$ & $\begin{array}{l}\text { leadership, cooperation, and developmental } \\
\text { work } \\
\text { specialization course } \\
\text { bachelor's thesis }\end{array}$ \\
\hline
\end{tabular}

Table 2. Overview of areas of knowledge and the focus of the subject of pedagogy within them (undergraduate kindergarten teacher education, Norway).

\begin{tabular}{|c|c|c|}
\hline $\begin{array}{c}\text { Course } \\
\text { year }\end{array}$ & Areas of knowledge & Focus of pedagogy \\
\hline $1^{\text {st }}$ & $\begin{array}{l}\text { Child development, play, } \\
\text { and learning } \\
\text { Art, culture, and creativity }\end{array}$ & $\begin{array}{l}\text { the child as a subject } \\
\text { holistic approach to play } \\
\text { leadership of children's } \\
\text { groups } \\
\text { the playing teacher } \\
\text { (through art-based } \\
\text { activities) } \\
\text { philosophical } \\
\text { conversation with } \\
\text { children }\end{array}$ \\
\hline $2^{\text {nd }}$ & $\begin{array}{l}\text { Nature, health, and motion } \\
\text { Language, text, and } \\
\text { mathematics } \\
\text { Social sciences, religion, } \\
\text { and ethics }\end{array}$ & $\begin{array}{l}\text { didactic planning } \\
\text { leadership of staff/unit } \\
\text { leadership of children's } \\
\text { groups } \\
\text { challenges in play }\end{array}$ \\
\hline $3^{\text {rd }}$ & $\begin{array}{l}\text { Leadership, cooperation, } \\
\text { and developmental work } \\
\text { Specialization course } \\
\text { Bachelor's thesis }\end{array}$ & $\begin{array}{l}\text { leadership of the } \\
\text { kindergarten unit, } \\
\text { parental cooperation, } \\
\text { cooperation in other } \\
\text { instances and with other } \\
\text { actors important in the } \\
\text { lives of children with } \\
\text { special needs }\end{array}$ \\
\hline
\end{tabular}

Courses in the areas of knowledge above take place on campus and are followed by 100 days of practice during the three years of the course of study. Each year of practice has its goals. In brief, it comprises leading a group of children and supporting their developmental activities in the first year of the course of study; applying professional tools and reflecting critically on one's own actions and leading the staff and children's groups is the focus of the second year of the course of study; and planning and conducting a developmental project, leading the staff and using documentation as a tool for reflection and improvements are the focus of the third year of the course of study.

In the institution where the reported research was 
conducted, a special interdisciplinary project joining together all teachers involved in the area of knowledge social sciences, religion, and ethnics was also developed and was entitled the Difficult Conversation [see: 18] which was run in the form of a two-week workshop that began with lectures and followed by participants doing their own reading, and drama-based exercises aimed at developing the best solutions for real-life problems connected to parental cooperation in a diverse society.

\section{The Institutionalization of Kindergarten Teacher Education - a University from Croatia}

Kindergarten teacher education at the Croatian university that participated in this study is conducted on both undergraduate and graduate levels. The undergraduate bachelor's degree program is compulsory for becoming a kindergarten teacher. No specializations or profiles are chosen at this level. The tables below present an overview of the subjects that students are introduced to during each year of the undergraduate course of study.

Table 3. Overview of subjects during the three-year undergraduate kindergarten teacher education program at the Croatian university participating in the present study.

\begin{tabular}{|c|l|}
\hline $\begin{array}{c}\text { Course } \\
\text { year }\end{array}$ & \multicolumn{1}{|c|}{ Subjects presented to the students } \\
\hline $1^{\text {st }}$ & $\begin{array}{l}\text { pedagogy, psychology, art, music, language, literacy, } \\
\text { kinesiology, science, ICT and media education, social } \\
\text { and emotional development, health }\end{array}$ \\
\hline $2^{\text {nd }}$ & $\begin{array}{l}\text { philosophy, pedagogy, teaching profession, } \\
\text { kinesiology, language, art, music }\end{array}$ \\
\hline $3^{\text {rd }}$ & $\begin{array}{l}\text { pedagogy, psychology, art, music, language, literacy, } \\
\text { kinesiology, statistics, bachelor's thesis }\end{array}$ \\
\hline
\end{tabular}

There are three main activity settings provided by the university that are connected to: a) lectures to introduce theoretical knowledge; b) didactic trainings aimed at developing practical knowledge that are conducted through workshops or exercises in kindergartens; c) practical training in various kindergartens. While lectures at the university are held in all three years of the course, the methodic trainings are in the second and third years of the course of study and together they comprise 41 ETCS credits and 375 hours. Practical training in kindergartens of 200 hours and 10 ETCS credits is divided among the three years of the course of study $(40 \mathrm{~h}, 80 \mathrm{~h}$, and $80 \mathrm{~h}$, respectively). This means that the course of study starts with rather theoretical content and finishes with a focus on practice and profession-related issues.

Since the current study focuses on students' perceptions of pedagogy and its role in their education, Table 4 below presents the focus of pedagogy during the years of the course of study. The table does not include the content of other subjects, but the students relate the pedagogical to the other disciplines that they are introduced to.

Table 4. Overview of the focus of the subject of pedagogy during the undergraduate kindergarten teacher education program at the Croatian university participating in the present study. Source: Own elaboration.

\begin{tabular}{|c|l|}
\hline $\begin{array}{c}\text { Course } \\
\text { year }\end{array}$ & \multicolumn{1}{|c|}{ Focus of pedagogy } \\
\hline $1^{\text {st }}$ & $\begin{array}{l}\text { understanding child development } \\
\text { understanding individual approaches } \\
\text { knowing the influence of exercise } \\
\text { self-evaluation }\end{array}$ \\
\hline $2^{\text {nd }}$ & $\begin{array}{l}\text { understanding the best interests of children } \\
\text { inclusive pedagogy } \\
\text { understanding creativity }\end{array}$ \\
\hline $3^{\text {rd }}$ & $\begin{array}{l}\text { understanding contemporary childhood and the } \\
\text { concept of children's rights }\end{array}$ \\
\hline
\end{tabular}

Since the university has autonomy in creating the study programs, it can respond more quickly to societal changes. The new program for the 2018-19 academic year includes more emphasis on the contemporary approaches to pedagogy and childhood. Courses such as information communication technology in education, socio-emotional development, inclusive pedagogy, family and school partnerships, and childhood and children's rights provide students with more relevant knowledge. The new program is also based on understanding kindergarten teachers as reflective practitioners who combine theoretical knowledge, ethics, and experience in their professional actions. Nevertheless, the students who participated in the study reported on herein followed the content described in Table 4.

\section{Conceptual Framework for Grasping Professional Competence}

Although early childhood education is part of a formal educational system in which different professions appear to be the bearers of education $[19,20]$, it is kindergarten teachers who safeguard the quality of education and care processes and their coherence with steering documents. The role of teachers is to help children to achieve their developmental potential and facilitate group processes among children in co-operation with the families of these children. In Norway, kindergarten teachers have often leadership responsibilities with regard to non-qualified staff and fellow kindergarten teachers. What makes the position of kindergarten teacher a profession is the specific professional knowledge that is required to conduct these tasks, but also its relation to societal challenges and needs connected to the necessity of childcare in order to provide women with equal opportunities in the labor market and to fulfil children's rights to education and care. Moreover, it also addresses the ethical and moral responsibility that 
implicit in everyday work situations [21].

Professional knowledge and competencies are crucial when talking about this profession $[20,22,23,24,25,26$, $27,28]$

In the Croatian context, the competences that are a fundamental part of the undergraduate education are as follows: competences for effective teaching, lifelong learning, management and communication, assessment and evaluation, and general professional competence: positive attitude toward children, trust in children's opportunities, adherence to principles, managing one's own professional development, promoting positive values, successful communication with parents, cooperating with the local community, and openness to others [22]. It remains unclear whether the competences acquired by undergraduate education correspond to the competences needed in practice.

Other authors [20,23, 25] emphasize the importance of the personal characteristics of teachers as a component of professional competence. Gordon and Browne [23] consider that, with professional knowledge, professional competencies of teachers should include personal qualities that include dedication, compassion, a sense of humor, flexibility, patience, vigor, and self-confidence. Liakopoulou [25] points out that the competences of teachers, together with pedagogical skills and knowledge, should include personal attitudes and beliefs. Gasper [20] also equates educational competences with academic knowledge and positive characteristics. Academic knowledge encompasses competences in the field of expertise and is the easiest to define because it refers to the content of what the teacher will do. Personal characteristics are more difficult to identify and are probably the subject of subjective assessment, so it is possible these are rarely seen as part of professional competence.

Vukašinović [29] gives an overview of the competences as high-quality theoretical knowledge, appropriate professional skills, and knowledge of the content and structure of current kindergarten programs. Višnjić Jevtić [30] states that the education programs for teachers in the Republic of Croatia result in the development of key competences for lifelong learning, while Vujičić, Tatalović Vorkapić, and Boneta [26] emphasize that, apart from the development of the knowledge and skills of teacher, it is necessary to develop attitudes toward professional development and a willingness to accept the role of researcher.

Marfuga et al. [27] consider that competence develops through education and transforms into a professional quality. According to these researchers, the quality of teachers includes personal qualities, professional readiness for pedagogical activity, and interaction with learning processes. Competence is defined as a flexible, universal, pragmatic concept that includes the ability to analyze systematically, increase psychological and intellectual openness to innovative changes in the environment, cultures of thinking, behaviors, and communication as the fundamental conditions for acting in society, and a constant aspiration for continuous self-education.

In their exploration of these competences, Mohamed, Valcke, and De Wever [28] developed an international framework of educational competencies. Within this framework, teachers should have knowledge, organizational and pedagogical skills; the ability to establish partnerships with parents, professionals, and the community; develop professionally, and behave in accordance with professional ethics. 
Table 5. Comparative representation of components of the professional competences of kindergarten teachers

\begin{tabular}{|c|c|c|c|c|c|c|c|c|}
\hline & Knowledge & $\begin{array}{c}\text { Leadership and } \\
\text { teaching skills }\end{array}$ & $\begin{array}{l}\text { Ability to cooperate } \\
\text { and maintain } \\
\text { partner-ships }\end{array}$ & $\begin{array}{l}\text { Continuous } \\
\text { professional } \\
\text { development }\end{array}$ & $\begin{array}{l}\text { Professional ethics, } \\
\text { ability to make } \\
\text { ethnical choices }\end{array}$ & $\begin{array}{l}\text { Personal } \\
\text { qualities }\end{array}$ & $\begin{array}{l}\text { Compe-tence } \\
\text { to act }\end{array}$ & $\begin{array}{c}\text { Use of } \\
\text { professional } \\
\text { language in daily } \\
\text { situations }\end{array}$ \\
\hline $\begin{array}{l}\text { Peklaj, Marentić Požarnik } \\
\text { and Puklek Levpušec } \\
\text { (2005) }\end{array}$ & $\checkmark$ & $\checkmark$ & $\checkmark$ & $\checkmark$ & $\checkmark$ & & & \\
\hline $\begin{array}{c}\text { Miles Gordon and } \\
\text { Williams Brown (2010) }\end{array}$ & $\checkmark$ & $\checkmark$ & $\checkmark$ & & & $\checkmark$ & & \\
\hline Selvi (2010) & $\checkmark$ & $\checkmark$ & $\checkmark$ & $\checkmark$ & & & & \\
\hline Liakopoulou (2011 a) & $\checkmark$ & $\checkmark$ & & & & $\checkmark$ & & \\
\hline $\begin{array}{c}\text { Kopas Vukašinović } \\
\text { (2012) }\end{array}$ & $\checkmark$ & $\checkmark$ & & & & & & \\
\hline $\begin{array}{c}\text { Vujičić, Tatalović } \\
\text { Vorkapić, and Boneta } \\
\text { (2012) }\end{array}$ & $\checkmark$ & $\checkmark$ & & $\checkmark$ & & & & \\
\hline Marfuga et al.(2013) & $\checkmark$ & $\checkmark$ & & $\checkmark$ & & $\checkmark$ & & \\
\hline Gasper (2015) & $\checkmark$ & $\checkmark$ & & & & $\checkmark$ & & \\
\hline $\begin{array}{l}\text { Mohamed, Valcke, and } \\
\text { De Wever (2017) }\end{array}$ & $\checkmark$ & $\checkmark$ & $\checkmark$ & $\checkmark$ & $\checkmark$ & & & \\
\hline $\begin{array}{c}\text { Eik, Steinner \& Ødegård } \\
2016\end{array}$ & $\checkmark$ & $\checkmark$ & $\checkmark$ & & & & & $\checkmark$ \\
\hline Aasen 2012, 2018 & $\checkmark$ & $\checkmark$ & & $\checkmark$ & $\checkmark$ & & $\checkmark$ & $\checkmark$ \\
\hline $\begin{array}{l}\text { Hennum \& } \\
\text { Østrem } 2016\end{array}$ & $\checkmark$ & $\checkmark$ & & & $\checkmark$ & & $\checkmark$ & $\checkmark$ \\
\hline $\begin{array}{l}\text { Van Manen } \\
1993\end{array}$ & $\checkmark$ & & & & & & $\checkmark$ & $\checkmark$ \\
\hline
\end{tabular}


What is unique to the profession of kindergarten teacher in both Croatia and Norway is the combination of theoretical knowledge with the ability to make ethical judgements and undertake ethical actions, particularly in the context of instant action [31,32]. The competence to act is understood as the connection between professional knowledge and practice, such as professional and ethical judgements that are involved in work with children and adults. The professional academic knowledge intercutting this practice can be described as the intersection of general/academic and situated knowledge [33]. In other words, this creates a canon of knowledge on children, their development, rights and needs together with practical solutions that work and that make children feel respected, involved, and satisfied. The presence of these two kinds of knowledge are crucial for the professional exercise. Max van Manen [32] underlines the active character of the profession of teacher, in which the profession and professional knowledge are actualized by the actions of the teachers in their interactions with children and parents. It is, however, important that in the daily context of instant action one creates a level of acting in which reflection and the judgement of situations unify with theoretical knowledge. Professional action happens at the intersection of theoretical and ethical knowledge.

In the cultural-historical approach, professional and reflective actions are strongly connected to the language $[34,35]$ and concepts being used. With professional kindergarten teachers, this is related to using theoretical and professional categories to reflect on the values, policies, theories, and personal abilities that shape their acts. The competence of justifying their own actions through the use of theoretical toolkits, especially in relation to other teachers, professionals, non-qualified staff, and parents or children's caregivers is of great importance to the profession. Nevertheless, it is reported that professional language is used infrequently in the daily goings-on of kindergartens, especially in interactions with non-qualified staff $[31,36,37,38,39]$. This is problematic for the professional exercise since professional language must be spoken in order to actualize various phenomena that occur within the complexity of children, parental, and staff groups and in order to facilitate professional understandings of them $[36,40]$ and facilitate reflection and improvement. Utilizing professional concepts in ongoing practice is the only way to support professional reflection upon one's own practice, which is of particular importance to following the ideal of the reflective practitioner. Using professional language conditions the professional exercise of kindergarten teachers. If professional language and reflection are not used with professional concepts, the professional exercise becomes tacit knowledge or skill-related knowledge with the character of "know-how" [41, 42] that results in the unconscious, unprofessional reproduction of certain practices [43].

\section{Reconstructing the Student Perspective - Study Methodology}

According to Hedegaard $[1,4]$ who draws on the work of Vygotsky and Leontiev, the individual perspective can be described with the phenomenon of activity, which refers to actions that are undertaken and the motives that underlie them or come afterward. According to Leontiev [44: 23] a subject "who experiences reality" is a "subject who perceives, thinks, and feels, but first and foremost he acts in relation to this reality." All three authors underscore the complexity of activity and all of its interwoven aspects.

Our understanding of activity is connected to motives developed by institutional conditions and certain activities that kindergarten teacher education students perceived as supporting their professional development. The students were interviewed in groups of five to six students. Two of these groups of third year students were interviewed in Norway and in Croatia. Altogether, four groups of students were interviewed: a) group 1 - Norway - 5 students (females); b) group 2 - Norway -6 students (4 females, 2 males), c) group 3 - Croatia 14 students (females) d) group 4 - Croatia - 12 students (females).

The main questions asked of the students were: 1) How do you perceive your course of study (kindergarten teacher education)?; 2) How do you perceive the role of pedagogy in your professional learning/formation? Since the questions were very general and the students were encouraged to discuss them among themselves and to follow the directions the discussions took; thus, the content of the discussions differed among the groups. However, before discussing their own perceptions, the students discussed their own expectations of the education in terms of which competences are crucial for the profession. Later, they discussed various instructional practices and activity settings as either supportive or unsupportive of their professional development.

The group interview was chosen in order to reconstruct joint/collective understandings of the role of certain institutional practices in the students' professional formation [45, 46]. Interviewing the students in collectives/groups was intended to support focusing on collective perceptions that are rooted in the commonality of social experience [45]. The length of the group discussions ranged from 60 to 90 minutes each, and they were transcribed into a total of 61 pages of text. The interviews took place in March 2015 in Norway and in October 2016 in Croatia.

Ethics. All the research participants were informed about the purpose of the research project and the group interviews. Participation in the interviews was voluntary, and the students were informed about the possibility of withdrawal at any stage of the interview. The participants were guaranteed confidentiality, beneficence, and non-maleficence. Moreover, the formal guidelines, which were dependent on approval from the Norwegian Center 
for Research Data and the Ethical Principles of the university in Croatia, were followed. However, since the project did not gather personal or sensitive data, as such data were defined in 2015 and 2016, it was not necessary to acquire any formal approvals.

Researchers. Both of the researchers were also the academic pedagogy teachers of the students who participated in the project; however, they did not have classes with the students in the academic year in which the interviews were conducted. Moreover, the students and the teachers knew that they would not meet in any teacher-student capacity during the subsequent year of the study. This means that and eventual power relations were connected to the past. Nevertheless, the students were ensured that participation in the project or withdrawal from it will not influence their studies or performance in any manner.

Data analysis. The data were analyzed with qualitative content analysis [47] that aims to systematically analyze the data by processing the empirical material using a category system. The main category that we aimed to reconstruct using the research material and that was central to the analysis was: conditions for professional development. The analysis focused then on the systematic search for traces of conditions for professional development in the research material and in categorizing the material [46].

The analysis of the Norwegian part of the data generated allowed for reconstructing student perceptions of the conditions for developing competences that the students themselves saw as important to their professional formation. The competence that the students developed that was crucial for their professional exercise was "the use of professional language in socially difficult settings" [Student_4_Group1]. The activity settings that were designated as supportive for this professional competence were: a) drama-based interdisciplinary projects that provided opportunities to role-play exercises of professional argumentation in socially uncomfortable settings; b) discussions on practical cases in groups where use of pedagogical concepts was required. These categories were then supplemented with the excerpts from the transcripts that provided insight into the students' perspectives on how these activity settings contributed to the professional competence of using professional language in socially difficult settings, and, thereby, to students' professional development.

The analysis of the Croatian empirical material permitted reconstructing the categories connected to practice of reflective discussions and motivations as the most important conditions for the students' professional growth. However, conditions were not only related to fulfilling formal demands since the students did not perceive the kindergarten teacher education program "as astrophysics, so all of us will graduate" [Student_1_Group1]. This meant that professional growth was also connected to certain informal practices or practices that can be safeguarded by general, formal regulations.

\section{Results from One Norwegian Higher Education Institution}

\subsection{The Crucial Professional Competence}

As mentioned above, the competence that was perceived by the students as being crucial for their professional exercise was "the use of professional language in socially difficult settings" [Student_4_Group1], which was also described as follows:

So, on the one hand, knowledge and then the ability to access and articulate it when you most need it and when it's so difficult to remember that you know it. Mastering this is what we absolutely need most in this profession [Student_5_Group2];

It's like finding good professional arguments when the whole situation is difficult to handle for you as a human being [Student_1_Group1];

To be able to find the right words that are rooted in professional knowledge, you know... and not least, be able to articulate them, even though the whole social setting may very uncomfortable for you, when you talking with your bosses or parents who are older and feel that they know better...or when you feel that your personal emotions are taking over [Student_3_Group2]; It's like keeping the peace insight yourself and then getting an overview over certain theories or concepts in your mind and then articulating them, even though the whole situation is difficult socially, emotionally, or for any other reasons [Student_1_Group2].

This competence was not, however, only connected to meetings and social settings with other staff or parents. Situations with children were also mentioned as requiring the competence to act in the right way often through saying the right things that are anchored in current theoretical knowledge:

But we cannot limit this only to meetings with other adults that we are, in a way, dependent on. It is equally important when it comes to the children. To find the right words in conflict situations, to kind of recognize children's emotions automatically, but, at the same time, not instrumentally...to show recognition and respect to all children involved, for example, in a conflict, but at the same time to lose it, or to enable them to solve it by asking the right questions. But to do so, you need to internalize all the theory and also practice a lot...to make it yours [Student_2_Group2].

This also obviously refers to situations with children. I guess we agree here on that [approval from the group 
with the body language]. You know that to grasp that there is a conflict or that a child is struggling with some feelings, misses Mom, or has it difficult at home at the moment...this requires that you resonate with professional knowledge [Student_3_Group1].

\subsection{Activity Settings Facilitating Crucial Professional Competence}

The activity settings that were experienced as developing this professional competence were: a) drama-based interdisciplinary projects that provided possibilities to conduct role-play exercises of professional argumentation in socially uncomfortable settings; b) discussions of practical cases in groups in which the use of pedagogical concepts was required.

The first activity setting (a) was experienced by the students only one time during their education in form of the interdisciplinary project of the Difficult Conservation [18] The other occurred more often during lectures and workshops within various areas of knowledge, but this happened more in pedagogy classes within the areas of knowledge than in others. Even though the activity settings occurred during the course of study, the number of them was perceived by the students as insufficient.

\subsection{The Role of Pedagogy}

The subject of pedagogy was perceived by the students as essential to their professional formation; however, according to the students, the number of pedagogy class hours was insufficient. The students viewed the literature and campus-based teaching as very relevant to their professional growth. However, there were not enough hours for lectures, mentoring, or for making eventual contributions to produce good effects from the Difficult Conversation project.

\subsection{Student Strategies for Copying with a Deficit of Pedagogy Classes in Kindergarten Teacher Education Programs}

Since the students experienced "too few" pedagogy classes in their courses of study, some of them took responsibility for their own education and organized class-environments so that they would be more stimulating for their professional growth. This is, however, the one instance of coping with the perceived lack of class hours in pedagogy. The majority of students perceived an insufficient number of hours, but they took no actions to rectify this.

Those who did and spoke about it during the group discussions used to challenge themselves as a group and formed a learning community by arranging activities that were demanding and developed professional attitudes. The content of these was developed using pedagogical and professional literature that was recommended to them by senior students. The focus of the students' extracurricular activities was to act professionally and articulate professional knowledge during difficult, uncomfortable conditions. As an exercise to develop this, the students "kicked one another out of our comfort zones and pushed one another to behave professionally. Like on a trip in the cold and rain when we purposefully did not take tents. We slept in our sleeping bags outside, because it is more difficult to be caring, nice, and positive and to respect others when you are cold and wet. But it was a great exercise to overcome the ego (...) we also had role-plays of parental meetings, job interviews, and some conflict simulations in parental and children's groups. Then we thought together about solutions and tried to play them out" [Student_5_Group_2].

\section{Results from a Croatian University}

\subsection{Crucial Professional Competence and Conditions for Developing It}

The Croatian students defined professional competence as a fundamental competence to act, to implement their theoretical and academic knowledge in work with children, staff, and parents in order to support children's all-round development. In some cases, it seemed to be about developing their own experience-based practical knowledge that develops during didactic workshops in kindergartens.

Although we acquire knowledge here, we still need to use it in the kindergarten. We can do this during didactic workshops - we actually try it then [Student_8_Group2]

Other students seemed to expect more detailed instructions on how to implement certain subjects and theoretical issues in practice.

We learn how to work with children, and their parents, but this is not enough [Student_5_Group 2]

We do have some courses that are not applicable in kindergartens, for example, ICT in education, we don't learn any methodology on use it, we learn about hardware and software. And this course is closely connected nowadays with children; we should learn how to apply contemporary technologies in kindergartens [Student_1_Group_1]

The students perceived the methodic workshops in kindergartens that were held once weekly during the third year of the course of study as an institutional setting that is suppose to help them to develop and "polish" their practical skills. It seems that the institutional goal behind this activity setting is clear: to build a bridge between theory and practice by trying out theoretical knowledge in practice and improving oneself in the role of teacher. This, 
however, had its particular challenges. On the one hand, the children focused on the "here and now," which made them forget the plan and the progression between the weekly workshops with students.

I am confused. We should master our skills now. After all, we are third years students. We should have more practice to try out what we have learned. And still, we have methodic practice in kindergarten on Fridays. Both we and the children forgot what we talked about or did from week to week. We should practice for a few weeks in a row. Then we could really master our competences. [Student_4_Group_2]

The other challenge of weekly didactic training was associated with in-service teachers and their motivation to support the students at the intersection of theory and practice. The students articulated a need for the in-service teachers being up-to-date with contemporary theories and also qualified in student mentoring.

Some of the in-service teachers were very helpful. And some just did not want to help. They say that we should know what to do. I think that it is about their motivation. [Student_3_Group_1]

And ours as well. Some of us are not motivated at all. I mean, grades or passing exams are motivation. But it should be knowledge, not grades. It is up to us if we want to learn, we will find a way. Regarding on the mentors' help. Some of the mentors are great teachers, but they just do not know how to talk with students. [Student_1_Group_1]

All of this is to support students learning how to combine theory and practice, rather than face the fact that practice is about something different. The students really appreciated activity settings that allowed them to combine their theoretical and practical knowledge, while they were disappointed by facing the practical field as "giving up" their theoretical ambitions. One of the activity settings that conditioned the link between theory and practice was didactics.

It was great when we made didactical material. We should know what is encouraging and what is not. [Student_2_Group_1]

Yes, and the encouraging questions! It is important to know what to ask [the children]! [Student_7_Group_2]

And when! [Student_8_Group_2]

Generally, the more time spent with the children was seen as positive for professional growth. However, the students' motivation, involvement, and reflection afterwards depended on the institutional setting. The institutional settings were very different in terms of mentoring being provided by either academic or in-service teachers. Studying with the insecurity of how much support they would receive caused the students to focus on their own being and practice with the children. This independent acting and practicing with children was experienced as having had a positive influence on their professional growth.

I think that the most helpful thing is to have more contact with children. [Student_2_Group_2].

Beside the possibilities of applying knowledge in real kindergarten settings, the students also mentioned the importance of reflecting after the activities concluded. The students identified the reflective discussions with peers and academic teachers as a practice that supported their professional growth.

After activities in the kindergarten, the most important was that we had time to talk about them. I mean, the things that we did ok and not so ok. [Student_4_Group_1].

In some cases the presence of academic teachers was viewed as disturbing and a source of stress since this was associated with formal assessment by students.

I am not so confident with that especially in the presence of professors. It is because of grades. [Student_5_Group_1]

Well, I still think that is good to know what you have being doing right and what not. And to get new ideas. When we become real teachers, there will be no one to discuss this with. [Student_4_Group_1]

\subsection{The Role of Pedagogy}

Most of the students participating in the interviews indicated that the pedagogy or psychology courses contributed the most to the development of their professional competences. Early childhood pedagogy was named as the most important subject from a professional point of view. This is a first year theoretical course, and the further practical and methodic trainings build upon it. Thus, it was seen as a foundation for the profession of teacher. However, it was not related to practice when it was presented to the students during the first year.

"I know it is just theory, but it is important to know how to recognize stages of children's play. And their developmental stages. We may apply that later. Not at the moment, but later for sure" [Student_9_Group_2].

\section{Discussion: Facilitating Professional Development as Institutional Conditioning for Bridging Theoretical and Situated Learning}

When reflecting on their professional development and conditions for it, both Norwegian and Croatian students indicated that the subject of pedagogy with its scientific nature was involved in both the theoretical and practical aspects of the profession of kindergarten teacher. The bridging of theory and practice was significant for the students' professional growth, and they still viewed it as an 
issue that required stronger institutional conditioning and facilitation.

Both Croatian and Norwegian kindergarten teacher education programs involved university campuses and in-service kindergartens as the institutional aspects of the education program. The aims were to provide the students with opportunities to relate theoretical knowledge to real-life early childhood education settings [9]. Nevertheless, regulations at the state level do not designate diverse individuals at campuses or in-service kindergartens. In Croatia, in-service teachers do not have to have additional qualifications to mentor students doing practical training. In Norway these teachers are required to receive mentoring training (15 ECTS), but one of the articles in this issue [48] examines the set of core institutional differences between in-service kindergartens and academic campuses that were described as disrupting the path to developing smoother transitions between the academic and in-service worlds.

For the Croatian students, the implementation of knowledge seemed to be the most important professional skill, while the Norwegian students focused on the more detailed dimension of it that is professional articulation in socially uncomfortable settings (as these contexts are seen by them as those in which the application of the professional knowledge is most difficult). The various qualities of reflection on the intersection between theory and practice was noted as a result of various theoretical tools being used in the educational programs to reflect upon the profession of kindergarten teacher and one's own professional development. In Norway, some theories on the kinds of knowledge are used; for example, theoretical, experience-based, and tacit [31, 33, 41]. Knowledge about this seemed to facilitate students' reflections on the role of language and on the importance of the articulation of professional knowledge, and both are seen as certain dimensions of implementing theory into practice.

The data gathered in Norway show how difficult it was to use professional language when dealing with unplanned, socially uncomfortable situations. The students lacked access to professional language and the ability to articulate it when they most needed it. They felt they had a duty to employ professional discretion and judgement when the time available to find the right theories to relate to a situation was limited. Again, limited access to professional knowledge limited their space of action [41].

The data gathered in Croatia indicated the necessity of the campus-based teaching content being more related to kindergarten practice, so that possible ways of implementing theoretical knowledge were left to the students and their methodic workshops in kindergartens. The Croatian students also mentioned the importance of the in-service teachers who were responsible for their learning in real kindergarten settings. Since the motivation and qualifications of the in-service teachers hosting the students was highly varied, so too was the students' professional growth. In some cases, the experiences of the exchange of knowledge were very positive, while in others this depended on the students' individual motivation.

Our conclusions refer to the need to facilitate students' competences to act at the intersection of academic campuses and in-service kindergartens and to support students' reasoning using learned theories when interacting with children, parents, and other kindergarten staff. In our eyes, increasing drama-based activity settings during campus-based teaching and involving in-service teachers to a greater degree in academia-based teacher training could be the way forward. Drama-based classes create a safe framework for trying out various dimensions of theoretical knowledge, while the formal involvement of in-service teachers in academia could help keep their academic knowledge current, develop their mentoring qualifications, and strengthen their motivation to support future kindergarten teachers.

\section{Summary}

This article examines Norwegian and Croatian students' perspectives on their professional growth during undergraduate kindergarten teacher education programs. Competences in exploiting theoretical knowledge in real-life settings, competences to act, including verbally, in unplanned, challenging social settings in relation to children, parents, and other kindergarten staff are important to students. However, students perceived institutional conditions for developing these most important competences as insufficient during the courses of study. In Norway, some students took the initiative with student groups and provided themselves with the experiences that the institutions failed to provide. In our eyes it is, however, an institutional and not private responsibility to do this. Thereby, we conclude this paper by pointing out several institutional solutions that could strengthen the professional growth of students at the intersection of academia and in-service kindergartens. The solutions suggested refer to a) increasing role-play and drama-based classes on academic campuses that will allow trying out theoretical knowledge in various imagined practical settings; b) strengthening involvement of in-service teachers in campus-based education to keep them up-to-date with theory, mentoring qualifications, and motivation; c) introducing the students into theories on knowledge and professional development so that they receive a theoretical toolkit for reflecting on their own professional growth at the boundary of theory and experience-based knowledge.

\section{REFERENCES}

[1] M. Hedegaard. Strategies for Dealing with Conflicts in 
value Positions between Home and School: Influences on Ethnic Minority Student's Development of Motives and Identity, Culture \& Psychology, Vol.11, No.2, 187-205, 2005.

[2] M. Hedegaard. Children's Creative Modeling of Conflict Resolutions in Everyday Life as a Site of Learning and Development. In: K. Aronsson, M. Hedegaard, Ch. Højholt, O. Skjær Ulvik, Children, Childhood, and Everyday Life. Children's Perspectives. Library of Congress Cataloging-in-Publication Data, USA., 17-36, 2012.

[3] M. Hedeegaard. Institutional practice, cultural positions, and personal motives: Immigrant Turkish parents' conception about their children's school life. In: S. Chaiklin, M. Hedegaard \& U.J. Jensen, (Eds.) Activity theory and social practice, Aarhus University Press, Aarhus. 1999.

[4] M. Hedegaard. Children's development from a cultural-historical approach: Children's activity in everyday local settings as foundation for their development. Mind, Culture, and Activity, No. 16, 64-82. 2009.

[5] M. Fleer, M. Hedegaard, J. Tudge (Eds.). Childhood Studies and the Impact of Globalization: Policies and Practicies at Global and Local Levels. Routledge, New York and London. 2009.

[6] M. Fleer, M. Hedegaard. Children's Development as Participation in Everyday Practices across Different Institutions. Mind, Culture, and Activity, No. 17, 149-168, 2010.

[7] W. Aasen, A.R. Sadownik, Does the new kindergarten teacher education program in Norway provide good conditions for professional kindergarten teachers? Universal Journal for Educational Research... this special issue. Article 1.

[8] Nasjonal Organ for kvalitet i utdanningen [NOKUT]. Evaluering av førskolelærerutdanning i Norge 2010. Del 1: Hovedrapport. Online available from: https://www.nokut.no/contentassets/40568ec86aab411ba43 c5a880ae339b5/hovedrapport_flueva.pdf

[9] Norwegian Ministry of Education and Research, Nasjonale retningslinjer for barnehagelærerutdanningen. Oslo. 2012.

[10] B. Mendeš. Profesionalno obrazovanje odgojitelja predškolske djece: Od jednogodišnjeg tečaja do sveučilišnog obrazovanja. Golden marketing - Tehnička knjiga, Zagreb. 2018.

[11] United Nations. Convention on the Rights of the Child. 1989.

[12] S. Bašić. (Nova) slika djeteta u pedagogiji djetinjstva. In: D. Maleš (Ed.). Nove paradigme ranoga odgoja. Filozofski fakultet Sveučilišta u Zagrebu, Zavod za pedagogiju, Zagreb. 19-37, 2011.

[13] A. Miljak. Življenje djece u vrtiću: Novi pristupi u shvaćanju, istraživanju i organiziranju odgojno-obrazovnog procesa $u$ dječjim vrtićima. SM Naklada, Zagreb. 2009.

[14] K. Sylva. Foreword. In: D. Sommer, I. Pramling Samuelsson, K. Hundeide (Authors). Child Perspectives and Children's Perspectives in Theory and Practice. Springer, Dordrecht, Heidelberg, London, New York: Springer, v-viii, 2010.

[15] C. Clouder. Education for the Unexpected. Improving the
Quality of Children in Europe, Vol. 5, 74-81, 2014.

[16] M. Ebbeck, M. Waniganayake. Early childhood professionals: leading today and tomorow. Elsevier Australia, Marickville. 2003.

[17] Državni pedagoški standard predškolskog odgoja i naobrazbe [The State Pedagogical Standard of the Republic of Croatia]. Official Gazzete 63/2008.

[18] Y. Bakken, N. Carson, M. Ohm. The Difficult Conversation...this special issues, article 5

[19] P. Oberhuemer, I. Schreyer, M. J. Neuman. Professionals in early childhood education and care systems: European profiles and perspectives. Barbara Budrich Publishers, Farmington Hills. 2010.

[20] M. Gasper. Professional practice and early childhood today. In: M. Reed, R. Walker (Eds.). A critical companion to early childhood. SAGE, Los Angeles, London, New Delhi, Singapore, Washington. 255-268. 2015.

[21] B.A. Hennum, S. Østrem. Barnehagelæreren som profesjonsutøver. Cappelen Damm Akademisk. Oslo. 2016.

[22] C. Peklaj, B. Marentič-Požarnik, M. Puklek-Levpušček. Identification of existing and desired teaching competencies - and what next?. 2005. Online available on: http://www. atee2005. $\mathrm{nl} / \mathrm{search} /$ paperworks. php?contrid $=13$

[23] A. Miles Gordon, K. Williams Browne. Beginnings and Beyond. Wadsworth Cengage Learning, Belmont. 2010.

[24] K. Selvi. Teachers' Competencies. Cultura. International Journal of Philosophy of Culture and Axiology, Vol. 13, 167-175, 2010.

[25] M. Liakopoulou. The Professional Competence of Teachers: Which qualities, attitudes, skills and knowledge contribute to a teacher's effectiveness?. International Journal of Humanities and Social Science, Vol. 1, No. 21, 66-78, 2011.

[26] L. Vujičić, S. Tatalović Vorkapić, Ž. Boneta. Redefiniranje obrazovanja odgajatelja: analiza iskustava studiranja prve generacije sveučilišnog diplomskog studija na Učiteljskom fakultetu u Rijeci. In: H. Ivon, B. Mendeš (Eds.). Kompetencije suvremenog učitelja i odgajatelja - izazov za promjene. Filozofski fakultet u Splitu, Split, 151-161, 2012.

[27] A. Marfuga, A.Turalbayeva, M. Jandildinov, A. Moshkalov. Possibilities of the Professional Competence Formation of Future Teachers. Procedia - Social and Behavioral Sciences, Vol. 89, 906-910, 2013.

[28] Z. Mohamed, M. Valcke, B. De Wever. Are they ready to teach? Student teachers' readiness for the job with reference to teacher competence frameworks. Journal of Education for Teaching, Vol. 43, No. 2, 151-170, 2017.

[29] E. Kopas Vukašinović. Predškolska pedagogija u sistemu savremenog univerzitetskog obrazovanja budućih vaspitača. Metodički obzori, Vol. 7, No. 14, 83-91, 2012.

[30] A. Višnjić Jevtić, A. Kompetencije odgojitelja u „odgoju za budućnost“. In: I. Pehlić, E. Vejo, A. Hasanagić (Eds.). Suvremeni tokovi u ranom odgoju. Islamski pedagoški fakultet Univerziteta u Zenici, Zenica, 377-388 2012.

[31] W. Aasen. Teamledelse i barneahgen. Fagbokforlaget, Bergen. 2012. 
[32] M. van Mannen. Pedagogisk takt. Betydningen av pedagogisk omtenksomhet. Casper Forlag. Bergen. 1993.

[33] J. Lave, E. Wenger. Situated Learning - Legitimate Peripheral Participation. Cambridge University Press. Cambridge. 1991.

[34] M. M. Bahktin. The dialogic imagination: Four essays by M.M.Bakhtin. University of Texas Press, Austin, 1981.

[35] L. S. Vygotsky. Mind in Society. The Development of Higher Psychological Processes. Harvard University, Cambridge Press, 1978.

[36] L.T. Eik. Førskolelærerens profesjonsspråk. FOU i praksis. Akademisk Forlag, Trondheim. 2013.

[37] L.T. Eik, G.S. Steinnes, E. Ødegård. Barnehagelærerens profesjonslæring. Fagbokforlaget. Bergen. 2016.

[38] T. T. Jansen. En lærer underviser, hva gjør en førskolelærer. In: T. T. Jansen et al. (Eds.). Førskolelæreren. Pedagogisk Forum, Oslo. 2006.

[39] E. Johansson, K. Fugelsnes, E.L. Møreseth, M. Røthle, B. Tøfteland, B. Zachrisen. Verdipedagogikk i barnehagen. Universitetsforlaget. Oslo. 2015.

[40] E. Ødegård. Lederes faglige legitimitet og medarbeideres lojalitet; to sider av samme sak? FoU i praksis. Artikkelsamling fra konferanser om praksisrettet FoU i lærerutdanning. Akademika forlag, Oslo. 2013.

[41] M. Polyani. The tacit dimension. Doubleday, New York. 1966.

[42] G. Ryle. The Concept of Mind. Penguin, Harmodsworth. 1963.

[43] W. Aasen. Teamledelse i barnehagen. 2nd edition. Fagbokfolag, Bergen. 2018.

[44] A. N. Leontiev. Activity, consciousness, and personality. NJ: Prentice-Hall, Englewood Cliffs. 1978 (original work published 1975).

[45] R. Bohnsack. Documentary method and group discussions. In: R. Bohnsack, N. Pfaff, W Weller (Eds.). Qualitative analysis and documentary method in international educational research, 99-124, B Budrich, Opladen. 2010.

[46] L. Cohen, L. Manion, K. Morrison. Research Methods in Education ( $6^{\text {th }}$ Edition). Routledge Taylor \& Fancis Group. London and New York. 2007.

[47] P. Mayring. Qualitaitve Content Analysis. Qualititative Social Research Vol.1, No. 2, Atr. 20.

[48] H. Torsteinson. Kindergarten teacher students' experiences of value conflicts in kindergartens as educational institutions. Universal Journal of Educational Research 7(3A): 22-30. 2019. DOI: 10.13189/ujer.2019.071303. 